\title{
A Dynamic Panel Gravity Model Application on the Determinant Factors of Ethiopia's Coffee Export Performance
}

\author{
Wondesen Teshome Bekele ${ }^{1}$ · Fekadu Gelaw Mersha²
}

Received: 10 November 2018 / Revised: 19 March 2019 / Accepted: 21 March 2019 /

Published online: 2 April 2019

(c) The Author(s) 2019

\begin{abstract}
Ethiopia's coffee export earning percentage share in the total export has been rapidly waning over the last decades while it is the first commodity in currency grossing of the country. Since, this study analyses the determinant factors of Ethiopia's coffee exports (ECE) performance, in the dimension of export sales, via a more realistic model application, dynamic panel gravity model. It commences with the disintegration of the determinant into supply- and demand-side factors. It used short panel data that comprise 71 countries of consistent Ethiopia's coffee importers for the period of 11 years from 2005 to 2015. The panel unit root test of Harris-Tzavalis was made for each variable and applied the first difference transformation for the variables that had a unit root. The system model of a linear dynamic panel gravity model was specified and estimated with two-step general method moment estimation approach. The model results suggested that lagged ECE performance, real gross domestic product (GDP) of importing countries, Ethiopian population, Ethiopian real GDP, openness to trade of importing countries, Ethiopian institutional quality, and weighted distance were found to be the determinant factors of Ethiopia's coffee exports performance. The study also implied policies that would promote institutional quality or permits favorable market environments, supply capacity, trade liberalization, and destination with relatively cheaper transportation costs in order to progress Ethiopia's coffee exports performance.
\end{abstract}

Keywords Coffee exports · Dynamic panel model · Ethiopia - Gravity model · System model · Two-step GMM

Wondesen Teshome Bekele

Wondesen52@gmail.com

Fekadu Gelaw Mersha

Fekadugelaw1@gmail.com

1 Department of Statistics, Dire Dawa University, Dire Dawa, Ethiopia

2 Department of Agricultural Economics, Haramaya University, Dire Dawa, Ethiopia 


\section{Introduction}

The export trade in Ethiopia has been taking different policy measures to the improvement of its performance. In the last around three decades particularly, the Transitional Government of Ethiopia (TOE) along with the International Monetary Fund (IMF) and World Bank has undertaken liberalization and structural adjustment program to address the internal and external imbalance of the economy. The economic policy of TOE acknowledged the importance of increasing and diversifying the country's export to comfort currency shortages along with a free market-based economic path by different trade policies, strategies and trade liberalization measures.

In order to ensure adequate private capital participation in the export business by aiming at increasing export and foreign exchange earnings, the role of the state in foreign trade sector was minimized [20].

The Ethiopian People's Revolutionary Democratic Front (EPDRF) government also has been engaging some measures such as minimizing administrative and bureaucratic procedures to the simplification of export licensing, currency exchange rate determination based on daily interbank foreign exchange system, devaluation of the Birr and step-by-step liberalization of the foreign exchange market, giving $70 \%$ loan for export-related investment projects through the development bank of Ethiopia if investors cover $30 \%$ on their own, a preferential interest rate scheme is also introduced for exporters, which is less by $3.5 \%$ compared to the interest rate paid on non-export activity loans, and a foreign exchange retention scheme has been introduced which entitles exporters to retain $10 \%$ of theirs earning to hold in their account and to sell the $40 \%$ at a competitive rate, while submitting the remaining 50\% directly to the National Bank [13].

According to NPCE [13], Ethiopia's economy, like other developing countries, is based on agriculture exports for its foreign exchange earnings. For instance, in the 2015/16 fiscal year, GDP at current market prices reached 72.4 billion USD or 1.5 trillion Ethiopian birr; export to GDP ratio declined to $8.0 \%$. The weak performance of Ethiopia's export sector was the main restraint in undertaking a reliable and adequate supply of foreign exchange vital for imported capital goods and services during a five year implementation period. Since the export sector needs to be transformed to sustain economic growth and set the foundation for structural economic transformation.

The coffee export sector in Ethiopia is one of the highest contributors to the government treasury through taxation, social services, and trade. It also plays a crucial role in Ethiopia's economy by influencing economic growth and employment. Moreover, the most dynamic growth in African coffee production was observed in Ethiopia, which has recorded an average annual growth rate of $2.2 \%$ over the past 50 years, increasing to $2.7 \%$ since crop year 1989/90. Ethiopia is also unique in Africa in so far as it has a strong domestic coffee consumption culture, which frequently accounts for over half of production. Ethiopia remains the leading country in terms of domestic consumption with 3.7 million bags in 
2013/14, representing $71.6 \%$ of the total domestic consumption of Africa and $8 \%$ of all exporting countries [10].

However, the coffee export sector share in total exports declined from 36 to $32 \%$ in 2008-2012. The export unit price grew nearly 60\% between 2008 and 2011 but declined almost 20\% between 2011 and 2012 [10]. Given the role of Ethiopia's coffee export for the country economy, it is therefore important to understand the major influence of the supply- and demand- side factors to its trading partners.

As most of the African countries total exports which is more than $80 \%$ are primary commodities and the long term decline in prices, variability of export volume, deterioration in the terms of trade, and the instability of commodity markets are said to be major factors that affect export performance and constrain economic growth in Africa [21]. Ethiopia's export performance is also restrained by the real exchange rate, the distance between Ethiopia and its partners, supply-side factors: real GDP, Ethiopian average institutional quality, and trade policy, and demand-side factors: population, real GDP, and openness to trade [8, 24]. The former studies or export modeling in Ethiopia has been realized by different Econometrics techniques like time series- or panel- data type, static- or dynamic- nature of the model, and/or ad hoc- or theory- based export model.

Scholars have been signifying a more realistic export model that comprise three major components. Firstly, it better to apply theoretical export model like gravity model rather than using ad hoc approach of modeling [1]. Secondly, the use of panel data based modeling approach help to consider individual heterogeneity of trade partners and other attributes $[4,22]$. Thirdly, it should be a dynamic model that incorporate(s) lagged or past period (s) export as an exogenous variable(s) [4, 11, 22]. However, there is no empirical study in Ethiopia that comprises export model components once.

\section{Frameworks}

\subsection{Theoretical Frame}

The trade gravity model is the econometric model that often use for ex-post analyses of international trade flows as a baseline model for estimating the impact of a variety of policy issues. It is based on the idea that overall trade volumes between the two nations depend on the size of the two nations and the distance they are apart. Tinbergen and Poyhonen were the first authors to developed Gravity models of international trade. There are a couple of reasons for the central role played by the gravity model. The first has to do with its high explanatory power of on bilateral trade flows and enables us to incorporate dynamic effects among economies. The second reason is that it provides an easy method to test the role that other variables play in affecting trade $[1,7]$. The international trade Gravity models formerly given as follow:

$$
\mathrm{T}_{\mathrm{ijt}}=\mathrm{k}\left(\operatorname{GDP}_{\mathrm{it}}^{\alpha} \cdot \mathrm{GDP}_{\mathrm{jt}}^{\beta}\right) / \mathrm{DIS}_{\mathrm{ij}}^{\lambda}
$$


The basic formulation of the gravity model explains bilateral trade flows in analogy to Isaac Newton's law of gravity, by the attraction of two countries' masses (measured by GDP and/or population), reduced by the distance which is a proxy of transport costs and other factors. Some studies contributed to the refinement of the traditional explanatory variables and to the addition of new ones, and the others improve the econometric specification of the model [7, 14].

Some criticism about gravity model for its lack of theoretical foundations has emerged. Indeed, the former theoretical foundation of the gravity model derivation centered on constant elasticity of substitution preferences and goods that are differentiated by region of origin. Subsequent extensions of it used the differentiated product framework with increasing return to scale, encompass factor endowments and taste variables that explain the microeconomic foundations for the gravity equation based on monopolistic competition or Heckscher-Ohlin $(\mathrm{H}-\mathrm{O})$ structure that includes only the main variables such as GDPs, population and distance. Particularly, the gravity model can incorporate additional variables to control for the differences in factor endowments that could aid or impede exports between countries [1]. Hence, the gravity model becomes;

$$
X_{i j}=\beta_{0} Y_{i}^{\beta_{1}} Y_{j}^{\beta_{2}} N_{i}^{\beta_{3}} N_{j}^{\beta_{4}} D_{i j}^{\beta_{5}} A_{i j}^{\beta_{6}} e^{Z M} e^{u_{i j}}
$$

where $\beta$ 's are parameters of the model. $X_{\mathrm{ij}}$ is the value of export flow into country $\mathrm{j}$ from country $\mathrm{i}, \mathrm{Y}_{\mathrm{i}}$ and $\mathrm{Y}_{\mathrm{j}}$ indicate the respective GDP for each country, $\mathrm{N}_{\mathrm{i}}$ and $\mathrm{N}_{\mathrm{j}}$ indicates the population for the exporter and importer, respectively. While $\mathrm{D}_{\mathrm{ij}}$ is the geographical distance between the countries capital cities, $\mathrm{A}_{\mathrm{ij}}$ represent other factors that could restrict or facilitate exports between countries, $e^{\mathrm{zm}}$ is a vector of dummy variables that capture specific factors, and $\mathrm{e}^{\mathrm{u}}$ is the error term.

Despite the fact that gravity model is formulated in the multiplicative form, the model can be linearized by taking natural logarithm of the model for estimation of the parameters $[7,14]$ :

$$
\ln \mathrm{X}_{\mathrm{ijt}}=\beta_{0}+\beta_{1} \ln \mathrm{Y}_{\mathrm{it}}+\beta_{2} \ln \mathrm{Y}_{\mathrm{jt}}+\beta_{3} \ln \mathrm{N}_{\mathrm{it}}+\beta_{4} \ln \mathrm{N}_{\mathrm{jt}}+\beta_{5} \ln \mathrm{D}_{\mathrm{ij}}+\sum \ln \mathrm{A}_{\mathrm{ijt}}+\sum \mathrm{ZM}+\mathrm{u}_{\mathrm{ijt}}
$$

where $\mathrm{u}_{\mathrm{ij}}$ is the error term.

Egger [7], Krugman and Obstfeld [11] and Nguyen [14] noted that the existence of sunk costs borne by exporters to set up distribution and service networks in the partner country may generate inertia in bilateral trade flows, and countries trading with each other at time $t$ will tend to trade more at time $t+1$ too. Incorporating dynamics, the standard gravity model of trade can be written as follows:

$$
\begin{aligned}
\ln \mathrm{X}_{\mathrm{ijt}}= & \beta_{0}+\beta_{1} \ln \mathrm{X}_{\mathrm{ij}, \mathrm{t}-1}+\beta_{2} \ln \mathrm{Y}_{\mathrm{it}}+\beta_{3} \ln \mathrm{Y}_{\mathrm{jt}}+\beta_{4} \ln \mathrm{N}_{\mathrm{it}}+\beta_{5} \ln \mathrm{N}_{\mathrm{jt}} \\
& +\beta_{6} \ln \mathrm{D}_{\mathrm{ij}}+\sum \ln \mathrm{A}_{\mathrm{ijt}}+\sum \mathrm{ZM}+\mathrm{u}_{\mathrm{ijt}}
\end{aligned}
$$

As a result, Eq. 2.4 implies that trade flow performance achieved in the previous year provides a basis for the trade flow activities in the current year $[4,11$, $14,22]$. 


\subsection{Conceptual Frame}

The measurement of the export performance has evolved significantly over time in two directions: multidimensional and one-dimensional measures. Export performance can be labeled either as one-dimension/single-proxy measures (that is covering one dimension with one proxy), as one-dimension/multiple-proxy measures, or as multi-dimensional/multiple-proxy measures. The decision to use one-dimensional/single-proxy measures results in testing every relationship hypothesized separately with each export performance measure in the design. It also explained the reason that one dimension of export performance relates in different manners to the determinants. And it should not be forced into a single composite measure for one dimension and must be tested separately [19]. Accordingly, the study used an approach so called as one dimension with one proxy which enables us to measure the coffee export sales (USD values) as a proxy for the ECE performance.

\section{Methodology}

\subsection{Data Sources and Variables}

This study used annual panel data of Ethiopia's coffee export and its 71 trade partners over the period of 2005-2015. The panel data has better efficiency than other data types and offer more variability, more degree of freedom and reduce the multicollinearity among explanatory variables, improve the reliability of the regression results [4]. The study comprised the following variables based on gravity model theory as $[6,14,24]$.

First, Ethiopia's Coffee Export (ECE) refers to the annual USD value of Ethiopian coffee exported to each selected 71 countries, included as a dependent variable. The data was extracted from the National Bank of Ethiopia database. The selected countries were consistent Ethiopian coffee importer (ECI) that are importing Ethiopia's coffee at least once in a year throughout the periods of the study, and are listed in Appendix-A.

Second, Real Exchange Rate (RER) measures the international competitiveness of goods produced domestically. To facilitate computation of the average real exchange rate, the study applied the IMF definition of the real exchange rate: real exchange rate as the price of domestic currency against foreign currency, i.e. $\mathrm{RER}=\mathrm{E} . \mathrm{P} * / \mathrm{P}$. Where $\mathrm{E}$ is the bilateral nominal exchange rate, $\mathrm{P} *$ is the foreign price index of the major Ethiopian exports and $\mathrm{P}$ is the Ethiopia consumer price index. Third, the Gross Domestic Product (GDP): Annual USD values of GDP (in Billions) were extracted from the IMF, IFS database. Fourth, the Distance (DIS) is a time-invariant variable. Data on the distance between Ethiopia and its ECI were collected based on the geographic distance between Addis Ababa and capital cities of the selected ECI countries. The data was measured in kilometers' $(\mathrm{km})$ and the data was obtained from www.distancefromto.net/.

Fifth, the Population (POP) is the total populations (in millions) of Ethiopia and selected ECI countries were obtained from WB, WDI database. It is used to measure 
the influence Ethiopia's and that of ECI degree of self-sufficiency and absorption effect. Sixth, Openness to trade (OPEN) implies an economy's openness to the flow of goods and services from around the world. It is computed as the total trade (the sum of exports and imports) of a country with the world economy divided by its real GDP. These data were obtained from IMF, IFS database. Seventh, Institutional Quality (IQ) as the world governance indicator (WGI) project estimates the institutional quality of a particular country in terms of six parameters: rule of law, political stability, and absence of violence or terrorism, voice and accountability, government effectiveness, regulatory quality and control of corruption. The rank out of $100 \%$ is given for each component. The average value or principally the geometric mean of the six components as a proxy for Ethiopia's institutional quality. These parameters were obtained from the WGI website.

\subsection{Model Specification}

The study adopted and used the econometric specification of the dynamic panel gravity model described on [6, 14, 24]. It specified as follows:

$$
\begin{aligned}
\operatorname{lnECE}_{\mathrm{ijt}}= & \beta_{0}+\sum_{\mathrm{l}=1}^{\mathrm{p}} \delta_{1} \operatorname{lnECE}_{\mathrm{ij}, \mathrm{t}-1}+\beta_{2} \operatorname{lnGDP}_{\mathrm{it}}+\beta_{3} \operatorname{lnGDP}_{\mathrm{jt}}+\beta_{4} \operatorname{lnPOP}_{\mathrm{it}}+\beta_{5} \operatorname{lnPOP}_{\mathrm{jt}} \\
& +\beta_{6} \operatorname{lnWDIS}_{\mathrm{ijt}}+\beta_{7} \operatorname{lnRER}_{\mathrm{ijt}}+\beta_{8} \operatorname{lnOPEN}_{\mathrm{it}}+\beta_{9} \operatorname{lnOPEN}_{\mathrm{jt}}+\beta_{10} \operatorname{lnIQ}_{\mathrm{it}}+\alpha_{\mathrm{i}}+\varepsilon_{\mathrm{ijt}}
\end{aligned}
$$

where ECE $_{\mathrm{ijt}}$ is the USD value of coffee export from country $\mathrm{i}$ (Ethiopia) to $\mathrm{j}$, its ECI countries at time $t, G D P_{i t}$ is gross domestic product of country $i$ in year $t$ and $\mathrm{GDP}_{\mathrm{jt}}$ is gross domestic product of country $\mathrm{j}$ in year $\mathrm{t}$ that indicate economic size, $\mathrm{POP}_{\mathrm{it}}$ is the population size of country $i$ at time $t$ and $\mathrm{POP}_{j \mathrm{t}}$ is the population size of country $\mathrm{j}$ at time $t$ and, WDIS $\mathrm{ijt}_{\mathrm{ij}}$ is weighted distance between country $\mathrm{i}$ and country $\mathrm{j}$ at time $\mathrm{t}$. Since physical distance $\left(\mathrm{DIS}_{\mathrm{ij}}\right)$ is a fixed variable overtime, $\mathrm{RER}_{\mathrm{ijt}}$ is real exchange rate at time $t, I_{i t}$ is institutional quality of Ethiopia's at time $t, \mathrm{OPEN}_{\mathrm{it}}$ is openness to trade country $i$ at time $t, O P E N_{j t}$ is openness to trade country $j$ at time $t$, and the unobservable error term is consists of the country specific unobserved error term, $\alpha_{i}$, and idiosyncratic disturbance term, $\varepsilon_{\mathrm{ijt}}$. This is assumed to follow a oneway error component model.

Several studies used the weighted distance to wipe-out the time-invariant nature of the variable distance instead of absolute distance to measure the distance between trading partners in order to get intuitive computations of the model [14, 24]. They used exporter's GDP as a weight variable. Since, transportation cost is the expenditure of the exporter. Mathematically, weighted distance is calculated as: $\mathrm{WDIS}_{\mathrm{ijt}}=\left(\mathrm{DIS}_{\mathrm{ij}}{ }^{*} \mathrm{GDP}_{\mathrm{it}}\right) / \sum \mathrm{GDP}_{\mathrm{it}}$. Where WDIS $\mathrm{ijt}_{\mathrm{ij}}$ is the relative (weighted) distance between trading partners, DIS $\mathrm{ij}_{\mathrm{ij}}$ is the physical geographical distance, GDP $_{\text {it }}$ is the gross domestic product of country $\mathrm{i}$ (Ethiopia) at time $\mathrm{t}$ and that $\sum \mathrm{GDP}_{\text {it }}$ is the sum of all GDPs of Ethiopia over the study period.

The national incomes of the countries are proxies by their GDP. GDP is a measure of the size of a country's economy, so countries with higher GDP are assumed to trade more than countries with lower GDP. The import demand for foreign countries 
is determined by their income. The higher income of the importing country implies greater demand for imports and thus for Ethiopia's coffee exports. Hence, the coefficients of GDPs are expected to be positive. The variable GDP for Ethiopia and ECIs was considered in real terms at constant USD prices with 2010 as the base year to account for inflation using the deflator, GDP deflator.

The coefficient of the population is used to measure the influence Ethiopia's and that of ECI degree of self-sufficiency and absorption effect. Ethiopia with large population size is expected to produce and export more due to economies of scale resulting from cheap labor. Conversely, it can also export less due to higher domestic absorption effect of larger population size. Thus, the coefficient of Ethiopia's population can be positive or negative. On other direction, ECI's with large population size is indicative of the potentially larger market size and is expected to import more. So, the coefficient of the ECI population is expected to be positive.

The weighted distance is indicative of the degree of trade resistance or the ability to stay in the trade process with the given transportation cost between the trade partners. The higher the distance, the higher the transportation costs and hence the coefficient is expected to have a negative sign.

The coefficient of the bilateral real exchange rate is incorporated as a measure for the relative price of foreign goods in terms of domestic goods. The bilateral real exchange rate is a measure of the international competitiveness of domestically produced goods. The real depreciation in the real exchange rate means that it takes fewer units of foreign currency to buy one unit of domestic currency. This makes domestic goods relatively cheaper, leading to an increase in exports due to higher foreign demand. While the appreciation in the real exchange rate in an economy is associated with loses in competitiveness because more units of foreign currency are required to buy one unit of domestic currency. This raises the price of exported goods and lowers that of imported goods, leading to an increase in imports due to higher domestic demand. Thus, the coefficient of the real exchange rate is expected to be negative.

Openness to trades is a measure of the ability of countries to exchange freely as a buyer or seller in the international market place. It is also a degree to which government hampers the free flow of foreign goods and services has a direct bearing on the ability of individuals to pursue their economic goals and maximize their productivity and well-being. Trade barriers emerge in the form of regulatory barriers. This determines in general economic efficiency and growth. As a result, the more open an economy is, as indicated by high trade freedom, the more it is expected to trade with other economies. Thus, it is expected that the coefficient will be positive.

Index values computed from the six measures of institutional quality was used in the study. A country with better quality institutions is expected to trade more than a country with poor quality institutions because institutions increase trade by reducing transaction costs. Hence, the sign of this variable is expected to be positive. 


\subsection{Robust Regression Model and Estimation}

\subsubsection{Linear Dynamic Panel Gravity Model}

Blundell and Bond [4] and Roodman [16] made a linear dynamic panel model for short panel data as Eq. 3.2. The dynamic relationships are characterized by the presence of lagged dependent variable among the regressors, in which Eq. $3.1 \mathrm{can}$ be rewritten by stacking the endogenous variable, $\mathrm{Y}_{\mathrm{it}}$ and its lag, $\mathrm{Y}_{\mathrm{i}, \mathrm{t}-1}$, as Ethiopia's coffee export (ECE) and gross domestic product (GDP), real exchange rate (RER), population (POP), institutional quality (IQ), openness to trade (OPEN), and weighted distance (WDIS) as the exogenous variable, $\mathrm{X}_{\mathrm{it}}$, with the unobservable error terms.

$$
\mathrm{Y}_{\mathrm{it}}=\delta \mathrm{Y}_{\mathrm{i}, \mathrm{t}-\mathrm{l}}+\mathrm{X}_{\mathrm{it}}^{\prime} \beta+\alpha_{\mathrm{i}}+\varepsilon_{\mathrm{it}} \quad \mathrm{i}=1,2, \ldots, \mathrm{N} ; \mathrm{t}=1,2, \ldots, \mathrm{T}
$$

where $\delta$ is $1 \times \mathrm{K}$ and $\beta$ is $\mathrm{K} \times 1, \alpha_{\mathrm{i}} \sim \operatorname{iid}\left(0, \sigma_{\alpha}^{2}\right)$ and $\varepsilon_{\mathrm{it}} \sim \operatorname{iid}\left(0, \sigma_{\varepsilon}^{2}\right)$ independent of each other and among themselves. The Eq. 3.2 with condition above are characterized by two sources of persistence over time. There is autocorrelation due to the presence of a lagged dependent variable between the regressors, and heterogeneity among the individuals. There are some basic problems introduced by the inclusion of lagged dependent variable. Since $\mathrm{Y}_{\mathrm{it}}$ is a function of $\alpha_{\mathrm{i}}$, it immediately follow that $\mathrm{Y}_{\mathrm{i}, \mathrm{t}-1}$ is also a function of $\alpha_{\mathrm{i}}$. So, the least square estimation of Eq. 3.2 leads to inconsistent estimation of $\delta$ and $\beta$. This is because the regressor $\mathrm{Y}_{\mathrm{i}, \mathrm{t}-1}$ is correlated with $\alpha_{i}$ and hence with the error terms. Thus, this study consider estimation when $\alpha_{i}$ is a fixed effect, $|\delta|<1$, the error $\varepsilon_{i t}$ is serially uncorrelated, and the panel is short.

The accuracy and efficiency of former classical estimators in dynamic fixed effects models have been the central issue. The inclusion of a lagged endogenous variable in a model where individual effects are present gives rise to the wellknown dynamic panel bias: the correlation between the lagged dependent variable and the individual effect makes the former endogenous, so that the estimates are inconsistent $[2,17]$. Instrumental variable (IV) estimators have therefore been proposed to tackle the endogeneity of the lagged dependent variable. However, the IV estimators are not accurate and efficient, when the equation become overidentified that would happens when the number of moments greater than the parameters [4].

The GMM estimator appealing advantage is the availability of "internal" instruments: the endogenous regressors are in fact instrumented by their previous realizations, properly chosen according to meaningful moment conditions. GMM estimates are now also easily implementable as the treatment for all the downsides of the classical LDPD estimators [4]. Roodman [17] stated dynamic panel estimators are general estimators designed for situations with (1) short panels; (2) a linear functional relationship; (3) one left hand side variable that is dynamic, depending on its own past realizations; (4) independent variables that are not strictly exogenous, meaning they are correlated with past and possibly current realizations of the error; (5) fixed individual effects; (6) heteroskedasticity and autocorrelation within individuals but not across them. 


\subsubsection{Generic Linear GMM Estimation}

Considering Eq. 3.2, there are more instruments available than regressors $(\mathrm{L}>\mathrm{K})$ when the model is overidentified. To satisfy the moment conditions as best as it can: making the vector of the empirical moment

$$
\frac{1}{\mathrm{~N}} \sum_{\mathrm{i}=1}^{\mathrm{N}} \mathrm{z}_{\mathrm{i}} \varepsilon_{\mathrm{i}}
$$

where $\varepsilon$ is the vector of the empirical residuals, as small as possible. Take an $\mathrm{L} \times \mathrm{L}$ symmetric positive-definite weighting matrix $\mathrm{W}$ and use it to define a quadratic function of the moment conditions that has the form:

$$
\mathrm{J}(\hat{\gamma})=\left[\frac{1}{\mathrm{~N}} \sum_{\mathrm{i}=1}^{\mathrm{N}} \mathrm{z}_{\mathrm{i}} \varepsilon_{\mathrm{i}}\right]^{\prime} \mathrm{W}\left[\frac{1}{\mathrm{~N}} \sum_{\mathrm{i}=1}^{\mathrm{N}} \mathrm{z}_{\mathrm{i}} \varepsilon_{\mathrm{i}}\right]=\frac{1}{\mathrm{~N}^{2}} \varepsilon^{\prime} \mathrm{ZWZ}^{\prime} \varepsilon
$$

Since, to minimize $\mathrm{J}(\hat{\gamma})$, it is possible to omit the term $\frac{1}{\mathrm{~N}^{2}}$, as it doesn't affect the value of $\hat{\gamma}$ that minimizes $\mathbf{J}(\hat{\gamma})$. It can thus equivalently write $\mathrm{J}(\hat{\gamma})=\varepsilon^{\prime} \mathrm{ZWZ} \mathrm{W}^{\prime} \varepsilon \mathrm{J}(\hat{\gamma})$ is define as the GMM criterion function. The GMM estimator is the minimizer of $\mathrm{J}(\hat{\gamma})$ : it is

$$
\begin{aligned}
& \hat{\gamma}_{\mathrm{GMM}}=\operatorname{argmin} \mathrm{J}(\hat{\gamma})=\left(\frac{1}{\mathrm{~N}^{2}} \mathrm{X}^{\prime} \mathrm{ZWZ} \mathrm{W}^{\prime}\right)^{-1} \frac{1}{\mathrm{~N}^{2}} \mathrm{X}^{\prime} \mathrm{ZWZ} \mathrm{Z}^{\prime} \mathrm{y} \\
& \hat{\gamma}_{\mathrm{GMM}}=\left(\mathrm{X}^{\prime} \mathrm{ZWZ} \mathrm{Z}^{\prime} \mathrm{X}\right)^{-1} \mathrm{X}^{\prime} \mathrm{ZWZ} \mathrm{Z}^{\prime} \mathrm{y}
\end{aligned}
$$

where $\mathrm{X}=$ independent and $\mathrm{Z}=$ instrumental variables.

The major concern in choosing an optimal weight matrix is about the efficiency of the GMM estimator [5]. The covariance matrix, S, of the moment conditions, weight the moments by the inverse of their covariance matrix. Which is given by: $S=\frac{1}{N} E\left(Z^{\prime} \varepsilon \varepsilon^{\prime} Z\right)=\frac{1}{N} E\left(Z^{\prime} H Z\right)$.

Hansen [9] found that the optimal weighting matrix that makes the GMM estimator efficient is the one that uses weights for each moment that are the inverse of their variances/covariances. The optimal choice is $\mathrm{W}_{\mathrm{EGMM}}=\mathrm{S}^{=1}=\left(\mathrm{Z}^{\prime} \mathrm{HZ}\right)^{=1}$. So that,

$$
\hat{\gamma}_{\mathrm{GMM}}=\left(\mathrm{X}^{\prime} \mathrm{Z}\left(\mathrm{Z}^{\prime} \mathrm{HZ}\right)^{-1} \mathrm{Z}^{\prime} \mathrm{X}\right)^{-1} \mathrm{X}^{\prime} \mathrm{Z}\left(\mathrm{Z}^{\prime} \mathrm{HZ}\right)^{-1} \mathrm{Z}^{\prime} \mathrm{y}
$$

Since, the feasible efficient GMM (FEGMM) estimator is instead become

$$
\hat{\gamma}_{\mathrm{FEGMM}}=\left(\mathrm{X}^{\prime} \mathrm{Z}\left(\mathrm{Z}^{\prime} \hat{\mathrm{H} Z}\right)^{-1} \mathrm{Z}^{\prime} \mathrm{X}\right)^{-1} \mathrm{X}^{\prime} \mathrm{Z}\left(\mathrm{Z}^{\prime} \hat{\mathrm{H} Z}\right)^{-1} \mathrm{Z}^{\prime} \mathrm{y}
$$

where $\hat{H}$ is a consistent estimate of $\mathrm{H}$. 


\subsubsection{System Model with Two-Step GMM Estimation}

First difference model estimation, before system model, is the former model for the estimation of linear dynamic panel model, which is applied to remove the unobserved individual effect of the model that is source of dynamic panel biases [2]. However, Blundell and Bond [5] explained the first difference transformation of Eq. 3.2 lost some information. Since, it is feasible to use system model which helps to get back the information discarded by the first difference transformation and to include more restrictive assumptions in order to make additional orthogonality conditions that construct more valid instruments available and efficiency gains achievable.

Blundell and Bond [5] confirm that a system model GMM estimator that uses the lagged first difference of the $y_{i t}$ series, $\Delta y_{i t}$, as instruments for the equation in levels, in accumulation to the use of the lagged levels of $y_{i t}$ as instrument for the first-differences equations.

Exploiting the standard mild assumption that $\mathrm{E}\left(\Delta \varepsilon_{\mathrm{it}} \alpha_{\mathrm{i}}\right)=0$ for $i=1,2, \ldots, N$ and $t=3, \ldots, T$, which requires that any change in the idiosyncratic term is not correlated with the individual effect, it have $\mathrm{T}-2$ additional linear orthogonality conditions: $\mathrm{E}\left(\Delta \mathrm{y}_{\mathrm{i}, \mathrm{t}-1},\left(\alpha_{\mathrm{i}}+\varepsilon_{\mathrm{it}}\right)\right)=0$.These new moment conditions allow to use the lagged first difference of the $y_{i t}$ series, $\Delta y_{i, t-1}$, as instruments for the equation in levels. Blundell and Bond [5] suggest a system model with two-step GMM estimator that stacks the model in levels and that in first differences.

$$
\left(\begin{array}{c}
\Delta \mathrm{y} \\
\mathrm{y}
\end{array}\right)=\delta\left(\begin{array}{c}
\Delta \mathrm{y}_{-1} \\
\mathrm{y}_{-1}
\end{array}\right)+\left(\begin{array}{c}
\Delta \mathrm{X} \\
\mathrm{X}
\end{array}\right) \beta+\left(\begin{array}{c}
\Delta \varepsilon \\
\alpha+\varepsilon
\end{array}\right)
$$

And estimate system model Eq. 3.6 using GMM with the following set of instruments $Z=Z^{\Delta}$ and $Z^{l}$, where the former correspond to the instruments for the model in first differences, and the $Z^{l}$ latter to those associated with the model in levels, such that

$$
\begin{aligned}
& \mathrm{Z}_{\mathrm{i}}^{\Delta}=\left(\mathrm{Z}_{\mathrm{i}}^{(\mathrm{y})}, \mathrm{Z}_{\mathrm{i}}^{(\mathrm{x})}\right) \quad \mathrm{Z}_{\mathrm{i}}^{\mathrm{y})}=\left(\begin{array}{ccccccc}
\mathrm{y}_{\mathrm{i} 0} & & & 0 & 0 & 0 & 0 \\
0 & \mathrm{y}_{\mathrm{i} 0} & \mathrm{y}_{\mathrm{i} 1} & 0 & 0 & 0 & 0 \\
0 & 0 & . & 0 & 0 & 0 & 0 \\
0 & 0 & 0 & 0 & \mathrm{y}_{\mathrm{i} 0} & 0 & \mathrm{y}_{\mathrm{i}, \mathrm{T}-2}
\end{array}\right) \\
& \mathrm{Z}_{\mathrm{i}}^{\mathrm{x})}=\left(\begin{array}{ccccccccc}
\mathrm{x}_{\mathrm{i} 0}^{\prime} & 0 & 0 & 0 & 0 & 0 & 0 & 0 & 0 \\
0 & \mathrm{x}_{\mathrm{i} 0}^{\prime} & \mathrm{x}_{\mathrm{i} 1}^{\prime} & 0 & 0 & 0 & 0 & 0 & 0 \\
0 & 0 & \cdot & . & 0 & 0 & 0 & . & 0 \\
0 & 0 & 0 & . & 0 & 0 & \mathrm{x}_{\mathrm{i} 1}^{\prime} & 0 & \mathrm{x}_{\mathrm{i}-2}^{\prime}
\end{array}\right) \\
& \mathrm{Z}_{\mathrm{i}}^{1}=\left(\begin{array}{cccccc}
\Delta \mathrm{y}_{\mathrm{i} 2} & 0 & 0 & 0 & 0 & 0 \\
0 & \Delta \mathrm{y}_{\mathrm{i} 3} & & 0 & 0 & 0 \\
\vdots & & 0 & 0 & 0 & 0 \\
0 & 0 & 0 & \Delta \mathrm{y}_{\mathrm{i}, \mathrm{T}-2} & 0 & \Delta \mathrm{y}_{\mathrm{i} 2}
\end{array}\right) \mathrm{Z}_{\mathrm{i}}^{\mathrm{S}}=\left(\begin{array}{ccccc}
\mathrm{Z}_{\mathrm{i}}^{\Delta} & 0 & 0 & 0 & 0 \\
0 & \Delta \mathrm{y}_{\mathrm{i} 2} & 0 & 0 & 0 \\
0 & 0 & \Delta \mathrm{y}_{\mathrm{i} 3} & 0 & 0 \\
0 & 0 & 0 & 0 & 0 \\
0 & 0 & \cdots & 0 & \Delta \mathrm{y}_{\mathrm{i}, \mathrm{T}-2}
\end{array}\right)=\left(\begin{array}{cc}
\mathrm{Z}_{\mathrm{i}}^{\Delta} & 0 \\
0 & \mathrm{Z}_{\mathrm{i}}^{1}
\end{array}\right)
\end{aligned}
$$


where the first row corresponds to $\mathrm{t}=3$ up to $\mathrm{t}=\mathrm{T}$ and $Z^{S}$ is instrumental variable for the system GMM estimator. The added moment restrictions can be written as: $\mathrm{E}\left(\mathrm{Z}_{\mathrm{i}}^{\mathrm{l}} \varepsilon_{\mathrm{i}}\right)=0$ with $\varepsilon_{\mathrm{i}}=\left(\begin{array}{c}\varepsilon_{\mathrm{i} 3} \\ \vdots \\ \varepsilon_{\mathrm{iT}}\end{array}\right)$

The system model consists of $(\mathrm{T}-2)$ stacked equations in first differences and $(\mathrm{T}-2)$ stacked equations in levels for $\mathrm{t}=3, \ldots, \mathrm{T}$. The system GMM estimator is:

$$
\hat{\gamma}_{\mathrm{GMMsystem}}=\left(\frac{\hat{\delta}}{\hat{\beta}}\right)=\left(\left[\Delta \mathrm{Y}_{-1}, \Delta \mathrm{X}\right]^{\prime} \mathrm{Z}^{\mathrm{s}} \mathrm{WZ}^{\mathrm{s}}\left[\Delta \mathrm{Y}_{-1}, \Delta \mathrm{X}\right]\right)^{-1}\left(\left[\Delta \mathrm{Y}_{-1}, \Delta \mathrm{X}\right]^{\prime} \mathrm{Z}^{\mathrm{s}}\right) \mathrm{WZ}^{\mathrm{s} \prime} \Delta \mathrm{y}
$$

Blundell and Bond [5] developed the moment conditions for the equations in levels and in the lagged differences as instruments that the additional moment's restrictions remain valid also in case of weak instruments and explicitly define the assumptions on the initial conditions that need to be satisfied for the system estimator to be valid.

System GMM estimator uses only the most recent lag of the first differences as instruments for the equations in levels, as the studies are already using the lagged levels as instruments for the equations in first differences. The use of additional lagged first-differences would result in redundant moment condition [5, 17]. Works of literature have paid attention to the choice of the weighting matrix for the onestep GMM procedure and for the first step in a two-step procedure. Windmeijer [23] found that two-step GMM performs better than one-step GMM in estimating coefficients, with lower bias and standard errors. And the reported two-step standard errors, with his correction, are quite accurate.

The specified model, considering the model in this empirical application, was replicated by following the Stata commands of Roodman [17]. According to Roodman [17], as a developer of the xtabond 2 code, discussed pointers for the proper estimation of dynamic panel estimators. First, short panel data is appropriate for the estimators. If $\mathrm{T}$ is large, dynamic panel bias becomes insignificant, and a more straightforward (standard or traditional) fixed effects estimator works. Second, include time dummies in the estimation helps to make assumption more likely to hold such as the autocorrelation test and the robust estimates of the coefficient standard errors assume no correlation across individuals and in the idiosyncratic disturbances. Last, but not least, report all specification choices' with these estimators involves many choices, and researchers should report the ones they make: difference or system GMM; first differences or orthogonal deviations; one or two-step estimation; and non-robust or Windmeijer-corrected.

\subsection{Specification Tests}

\subsubsection{Test for Validity of Instrument Sets}

Sargan [18] and Hansen [9] shown test for the assumption about the absence of any (asymptotic) correlation between the instrumental variables and the disturbances. 
In addition to the former assumption, the choice of "good" instruments lies in the potency of the correlation between the endogenous regressors and the instruments. Indeed, Blundell and Bond [5], show that a small correlation results in erratic parameter estimates. Moreover, Baltagi [4] showed that there is a significant amount of the deleterious effects of weak instruments. Sargan (Hansen) over identification restriction (OIR) test, which is given by:

$$
\mathrm{m}=\Delta \widehat{\mathrm{u}^{\prime} \mathrm{Z}}\left[\sum_{\mathrm{i}=1}^{\mathrm{N}} \mathrm{Z}_{\mathrm{i}}^{\prime}\left(\Delta \hat{\mathrm{u}}_{\mathrm{i}}\right)\left(\Delta \hat{\mathrm{u}}_{\mathrm{i}}\right)^{\prime} \mathrm{Z}_{\mathrm{i}}\right]^{-1} \mathrm{Z}^{\prime}(\Delta \hat{\mathrm{u}}) \sim \chi_{\mathrm{L}-\mathrm{K}}^{2}
$$

where $\mathrm{L}$ refers to the number of columns of $\mathrm{Z}$ and $\Delta \hat{u}$ denotes the residuals from a two-step estimation.

Under the assumption of no serial correlation in $\varepsilon_{i t}, \Delta \varepsilon_{\text {it }}$ follow an MA(1) process and, the series $\mathrm{y}_{\mathrm{i}, \mathrm{t}-2}, \mathrm{y}_{\mathrm{i}, \mathrm{t}-3}, \ldots, \mathrm{y}_{\mathrm{i}, \mathrm{t}-\mathrm{T}}$ are valid instruments for estimating this model. However, if $\varepsilon_{\mathrm{it}}^{\prime} \mathrm{s}$ are serially correlated, this series no longer constitutes a valid instrument set. This implies that one can test $\mathrm{H}_{0}$ or $\varepsilon_{i t}$ is serially uncorrelated against $\mathrm{H}_{1}$ by comparing the difference between Sargan and Hansen statistics corresponding to two instrument sets: $\mathrm{Z}_{0}$ contains the instruments defined by the series $\mathrm{y}_{\mathrm{i}, \mathrm{t}-2}, \mathrm{y}_{\mathrm{i}, \mathrm{t}-3}, \ldots$, $\mathrm{y}_{\mathrm{i}, \mathrm{t}-\mathrm{T}}$ and $\mathrm{Z}_{1}$ is an instrument set not dependent on the assumption of $\varepsilon_{i t}$ not being serially correlated. Indeed, to increase the test's power, one might be more specific for $\mathrm{H}_{1}$ and test $\mathrm{H}_{0}$ against $\mathrm{H}_{1}$ with the latter hypothesizing, denote the difference between the two Sargan and Hansen statistics by $\mathrm{DQ}_{\mathrm{sh}}$. Under the null this is distributed as $\chi_{\mathrm{p}_{0}-\mathrm{p}_{1}}^{2}$ where $\mathrm{P}_{0}$ and $\mathrm{P}_{1}$ are the number of instruments in $\mathrm{Z}_{0}$ and $\mathrm{Z}_{1}$, respectively.

\subsubsection{Test for the Absence of Serial Correlation in $\varepsilon$}

The existence of serial correlation in $\varepsilon_{i t}$ will typically overthrow the use of lagged values and first differences of the endogenous variable as instruments. So, it is crucial to test for such serial correlation. Arellano and Bond [2] proposed, that is made based on result of the model estimated in first differences. Let $\Delta \hat{\varepsilon}$ be the vector of residuals from the model in first differences, $\Delta \hat{\varepsilon}_{-2}$, its second lag value, and $\Delta \hat{\varepsilon}^{*}$ the reduction of the vector $\Delta \hat{\varepsilon}$ allowing computation of the product $\Delta \hat{\varepsilon}_{-2} \Delta \hat{\varepsilon}^{*}$. This test provides a measure of the importance of serial correlation of order 2 once the model is written in first differences. If they $\varepsilon_{\mathrm{it}}^{\prime} \mathrm{s}$ are serially uncorrelated given by $\Delta \varepsilon_{\mathrm{it}}=\varepsilon_{\mathrm{it}}-\varepsilon_{\mathrm{i}, \mathrm{t}-1}$ follow an MA (1) process and thus, are not correlated at order 2. On the contrary, if $\Delta \varepsilon_{i t}$ appears to be correlated of order two, one can infer that the disturbances $\varepsilon_{i t}$ exhibit some serial correlation. The test statistics is given by:

$$
\mathrm{m}_{2}=\Delta \hat{\varepsilon}_{-2}^{\prime} \Delta \hat{\varepsilon}^{*} / \xi^{1 / 2}
$$

The test is one-sided as it will exhibit positive serial correlation. As test statistic, $\mathrm{m}_{2}$ show that, under the null of no serial correlation in $\Delta \varepsilon_{\mathrm{it}}$ at order 2 . One rejects $\mathrm{H}_{0}$ of no serial correlation. 


\subsection{Panel Unit Root Test: Harris-Tsavalis (HT) Test}

Panel unit root tests of Harris and Tzavalis derived a unit-root test for a short panel that assumes the time dimension, $\mathrm{T}$, is fixed or short. Their simulation results suggest that the test has favorable size and power properties for $\mathrm{N}$ greater than 25 , and they report that power improves faster as $\mathrm{T}$ increases for a given $\mathrm{N}$ than when $\mathrm{N}$ increases for a given $\mathrm{T}$ in balanced panel data. HT assumed that is independent and identically distributed with constant variance across panels. Because of the bias induced by the inclusion of the panel means in this model, the expected value of the estimator is not equal to unity under the null hypothesis. Notice that, the HT test assumes that all panels share the same autoregressive parameter [4].

\section{Results and Discussion}

\subsection{Panel Unit Root Test (PURT)}

Harris-Tzavalis panel unit test described in methodology Sect. 3.5 requires crosssectional independence, which is a strong assumption to make in the macroeconomic environment. However, there is a way to manage this issue, such as by assuming that the cross-sectional dependence is following a common trend across cross-sections. Thus, the issue mitigated by subtracting period means across cross-sections from each individual observation to eliminate a possible trend common to all cross-sections. To remove the cross-sectional dependence from the individual panel the Stata command demean was used. Under the null hypothesis, the panel variables contain a unit root versus alternative stationary. The test statistic and $p$-values for each variable in level and the first difference are reported in Table 1.

Table 1 Panel unit root test results of the variables at level and first difference. Source: Own computation

\begin{tabular}{lll}
\hline & \multicolumn{2}{l}{ Harris-Tzavalis test statistic } \\
\cline { 2 - 3 } & Level & First difference \\
\hline Ethiopia's coffee exports & $-12.719 * * *$ & - \\
Ethiopia's GDP & $-8.579 * * *$ & - \\
Ethiopia's openness to trade & $-4.279 * * *$ & - \\
Ethiopia's institutional quality & $-19.698^{* * *}$ & - \\
Weighted distance & $-32.099^{* * *}$ & - \\
Real exchange rate & 8.309 & $-12.957 * * *$ \\
Real GDP & 3.197 & $-19.095^{*} * *$ \\
Population $^{\mathrm{a}}$ & 2.296 & $-13.767 * * *$ \\
Openness to trade $^{\mathrm{a}}$ & 2.108 & $-22.204 * * *$ \\
Ethiopia's population $^{\text {a }}$ & 3.383 & $-12.102^{* * *}$ \\
\hline
\end{tabular}

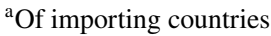

$* * *, * *$, and * represent 1,5 and $10 \%$ significance levels, respectively 
The tests suggested that five variables which are Ethiopia's coffee exports, Ethiopia's real gross domestic product, Ethiopia's measure of institutional quality, Ethiopia's openness to trade, and weighted distance, were stationary and no further adjustment is needed to make them stationary. The rest of the variables were unit root and the necessary adjustments were made to avoid the problem that arises from spurious regression. All variables which were a real gross domestic product of importing countries, Ethiopia's population, openness to trade of importing countries, real exchange rate, and the population of importing countries which were found to contain unit root when tested at the level were found to be stationary when tested after differencing.

\subsection{Dynamic Panel Data Model Estimation}

The robust regression result of the linear dynamic panel gravity model of Ethiopia's coffee export performance was estimated by two-step GMM estimation approach and presented in Table 2. It shows Ethiopia's coffee exports performance was found to be positively and significantly influenced by real gross domestic product and openness to trade of the importing countries, population, real gross domestic product, and institutional quality of the supply side or Ethiopia's, and lagged Ethiopia's coffee exports. But the weighted distance was found

Table 2 Ethiopia's coffee exports (ECE) performance model. Source: own computation

\begin{tabular}{lll}
\hline ECE performance by Two-step GMM estimate & \\
\hline Variables & \multicolumn{2}{l}{ System model } \\
\cline { 2 - 3 } & Coefficients ${ }^{\mathrm{a}}$ & WCSE $^{\mathrm{b}}$ \\
\hline One lag of ECE & $0.466(23.200)^{* * *}$ & 0.137 \\
GDP $^{\mathrm{c}}$ & $1.559(6.830)^{* * *}$ & 2.236 \\
Real exchange rate & $-0.107(-0.06)$ & 1.303 \\
Openness to trade & $1.045(3.080)^{* * *}$ & 1.617 \\
Weighted distance & $-0.640(-2.600)^{* * *}$ & 1.019 \\
Population & & 9.796 \\
Ethiopia's GDP & $-0.159(-0.08)$ & 0.184 \\
Ethiopia's openness to trade & $0.258(6.070)^{* * *}$ & 0.085 \\
Ethiopia's population & $1.308(9.810)^{* * *}$ & 0.999 \\
Ethiopia's institutional quality & $3.094(7.510)^{* * *}$ & 1.812 \\
No. of observations & 710 & \\
No. of groups & 71 & \\
No. of instruments & 73 & \\
\hline
\end{tabular}

${ }^{\mathrm{a}}$ Test statistics in parenthesis

${ }^{\text {b} W i n d m e i j e r ' s ~ c o r r e c t e d ~ s t a n d a r d ~ e r r o r s ~}$

${ }^{\mathrm{c}} \mathrm{Of}$ importing countries

$* * *, * *$, and * represent $1 \%, 5 \%$ and $10 \%$ significance levels, respectively 
to have a significant negative effect on coffee export. Finally, the remain three explanatory variables: the population of the importing countries, Ethiopia's measure of openness to trade index, and real exchange rate were found to be insignificant even at $10 \%$ level of significance.

The coefficient on real GDP of importing countries was found to be statistically significant at $1 \%$ level. The positive value is consistent with the theoretical prediction of gravity trade flow that anticipates that trade volumes increase with an increase in a partner's economic size. The estimated coefficient of 1.56 of the real GDP of importing countries suggests that a $1 \%$ increase in real GDP of importing countries will result in roughly a $1.56 \%$ increase in the flows of Ethiopia's coffee exports, ceteris paribus. Importing countries with larger GDP indicate for higher demand for Ethiopian coffee. This is consistent with the Orindi [15]. Using the gravity model, the study discovered that the real GDP of importing countries had a positive effect on the value of bilateral trade between Kenya and the 25 trading partners considered in the study for the years 1964-2008.

On the other hand, the estimated coefficient of Ethiopia's real GDP was 0.26 which implies that keeping other variables constant, a percent increase in Ethiopia's real GDP will result in roughly $0.26 \%$ increase in Ethiopia's coffee exports. Supplyside GDP improvement is an indication for better production power. The result is in conformity with the study on African countries used a dynamic panel data set for 48 African countries over the period 1987-2006 to identify the key determinants of export performance and found that supply capacity had a positive effect on the export performance [12].

Besides, Ethiopia's population was found to significantly and positively determine Ethiopia's coffee exports flow. The estimated coefficient was 1.31 which implies that keeping other variables constant, a $1 \%$ increases in Ethiopia's population results in a $1.31 \%$ increase in Ethiopia's coffee exports. It also indicates that the rate of adsorption in response to a change in population size is weaker. The result is consistent with Dlamini et al. [6], they analyzed the factors determining sugar export from Swaziland to trading partners using a gravity model and used annual panel dataset for the period 2001 to 2013, and found that exporter population had a positive effect on the performance of the export sector.

This study also found that the degree of openness to trade or trade liberalization implies a substantial reduction in tariff and non-tariff barriers has an undeniable impact in the bilateral trade process. The estimated coefficient for the degree of openness to trade of importing countries was 1.05 which means that, ceteris paribus, a percentage improvement in the degree of openness to trade increase Ethiopia's coffee exports flow to these countries by around $1.05 \%$. Thus, there the rise in Ethiopia's coffee over those periods can be attributed to the improvement in the openness of importing countries to trade. Hence, openness is an important determinant of Ethiopia's coffee export earnings and the improvements in the performance of Ethiopia's coffee exports can be partly attributed to the improvement in the openness of importing countries. The result is in conformity with the Babatunde [3] analyzed Sub-Saharan African export performance and used panel data set from 1980 to 2005 and found that the export performance of exporter's had influence by openness to trade of importers'. 
In addition, the level of export in the previous year was found to significantly affect the export performances of the subsequent year. A positive sign of the lagged ECE shows that the growth of Ethiopia's coffee exports flows in the preceding year has a positive effect on current year performance. The implication is that improving relationships with trading partners will improve the future performance of the country's exports. The estimated coefficient of lagged ECE was 0.466 which means that a percentage increase in the level of export to a country in the preceding year will result in around $0.47 \%$ increase the county's coffee exports flow in the current year, ceteris paribus. The result is in conformity with the Wacziarg [22] that attempted the respective roles of various theories of dynamic gains from trade using data from a panel of 57 countries from 1970 to 1989 in explaining the observed positive impact of trade on economic growth.

The estimated outputs additionally disclosed that Ethiopia's institutional quality coefficient was a positive value and statistically significant at $1 \%$ level. The estimated coefficient of Ethiopia's institutional quality was 3.09 which mean that a percent increase in Ethiopia's institutional quality will outcome around 3.09\% increase in Ethiopia's coffee exports flows, holding other variables constant. This outcome is in conformity with the anticipated theory that a higher Expected value is associated with better institutional quality. This determines in general markets environment and macroeconomic stability. Thus, the improvement on countries institutional quality is an indicator of advancement in the legal and judiciary system, taxation, labor relations, the financial system, investment procedures and customs administration [21].

The variable weighted distance was found to be statistically significant at $1 \%$ level. The result is also consistent with the theoretical expected negative sign in that the level of export declines as the distance between Ethiopia and its trading partners increases. The estimated coefficient of weighted distance was -0.64 which imply that the county's imports declined by $0.64 \%$ as the distance between Ethiopia and the importing county increases by $1 \%$, ceteris paribus. The result is consistent with the Yishak [24] that investigated determinants export performance of Ethiopia using panel gravity model approach in the period 1995-2007 consisting 30 major trade partners and he found that transportation cost had a negative impact on Ethiopia's export performance.

\subsection{Specification Tests}

The specification tests were held for each the system model, after model estimation. As shown in Table 3, the test statistics for second-order serial correlation of the models Arellano and Bond [2], shows there were no second order residuals correlations that reject the null hypothesis that states second order residuals of the model are correlated. The over-identification restrictions (OIRs) or joint validity of instrumental variables need to be tested. The study followed the conventional GMM test or Sargan and Hansen test statistics of over-identification restrictions. The study found that over-identification conditions (OIRs) are valid in the model. Since the null hypothesis claims that OIRs are valid, was failed to reject it. 
Table 3 Specification tests of the model. Source: Own computation

\begin{tabular}{lllr}
\hline System model & & & \\
\hline & Test statistics (TS) & TS-values & $p$ value \\
\hline $\mathrm{AR}(1)^{\mathrm{a}}$ & $\mathrm{Z}$ & -3.76 & $<0.001$ \\
$\mathrm{AR}(2)^{\mathrm{a}}$ & $\mathrm{Z}$ & -0.33 & 0.738 \\
Sargan test $^{\mathrm{b}}$ & Chi square & 64.04 & 0.189 \\
Hansen test $^{\mathrm{c}}$ & Chi square & 59.44 & 0.317 \\
Diff. hansen test $^{\mathrm{d}}$ & Chi square & 12.12 & 0.146 \\
\hline
\end{tabular}

${ }^{\mathrm{a}}$ Arellano-Bond test for AR (.) serial correlation

${ }^{\mathrm{b}}$ Sargan test of OIR

${ }^{\mathrm{c}}$ Hansen test for OIR

${ }^{\mathrm{d}}$ Difference in Hansen exogeneity test

As the difference in Hansen test statistics for the system model was performed to check whether the moment condition or additional restriction for the equations in levels or so-called untransformed equations are valid or not. As a result, the null hypothesis that claims as the addition moment restriction is valid was failed to reject it.

\section{Summary, Conclusion, and Policy Implication}

\subsection{Summary and Conclusion}

The core objective of this study has been to identify the main determinant factors of supply-and demand-side of Ethiopia's coffee export performance. To address this gap it used panel data consisting of the 71 Ethiopia's coffee importers in the period through 2005 up to 2015. This significance was selected concerning the gaps which were observed in the recent empirical literature. Predominantly, the gaps were in making a quantitative analysis. Given several extensions have been recommended to the basic gravity model to attain more reliable estimates of export trade, this study trusted to fill the gaps by assembly analyses via more realistic model, linear dynamic panel gravity model.

This study has been captures recent developments in the gravity estimation techniques to investigate the performance of coffee export between Ethiopia and importing countries specified and tested. It followed the empirical approach of $[6,14,22$, 24] which aids to organize the export performance of countries with sectoral level or disaggregated into supply-and demand-side factors, to use panel data, and to consider dynamic nature of the export model. It used secondary data extracted from the databases of NBE, IMF, and WB. Variable Ethiopia's coffee exports was used as dependent variable and the variables lagged ECE, weighted distance, Ethiopia's institutional quality, real exchange rate, and both demand- and supply-side of the variables: gross domestic product, population, and openness to trade were used as the explanatory variable. 
Before two-step GMM estimation of the specified linear dynamic panel gravity regression model, the study performed panel unit root test for each variable and first difference transformation for the variables that had unit root to tackle the problem of spurious regression. Then, heteroskedasticity test was made to evidence the empirical preference of GMM over IV methods.

Considering empirical output of this study, the results explained that the Ethiopia's coffee exports performance to the importing countries mainly depends on lagged Ethiopia's coffee exports, real gross domestic product of both importing countries and supply side or Ethiopia, weighted distance between Ethiopia and its importing countries, real gross domestic product of importing countries and openness to trade, and supply-side population and institutional quality, statistically significant. These variables were found to be positively associated with Ethiopia's coffee exports performance except that the variable weighted distance had negatively related. This conclusion is roughly in conformity with studies such as $[6,24]$. While the variable population of importing countries, Ethiopia's openness to trade, and the real exchange rate were found to be statistically insignificant.

\subsection{Policy Implication}

Based on this study result and conclusion, the possible recommendations can be drawn as:

Policymakers should give equal and better emphasis for demand and supply side factors determinants of ECE's performance provided that the importing countries or foreign market access conditions and the supply side factors will affect Ethiopia's coffee exports performance.

The Ethiopian coffee exporters should give more consideration to the destination of Ethiopia's coffee market with cheaper transportation costs. Since Ethiopia's coffee exports performance tends to decline over time as enhance the weighted distance between Ethiopia and importing countries which is proxy for transportation cost. Opportunity to increase Ethiopia's coffee market demand could be managed through effective policies which take geographical location or distance as merits in improving the competitiveness of Ethiopia's coffee market.

The positive and significant coefficients of the income or supply capacity which is proxy of real GDP suggests that macroeconomic policy reforms aimed at improving the growth of real GDP enhance Ethiopia's coffee exports performance. Thus, policies that guide to the progress of Ethiopia and importing countries economy should be promoted which will have effects on Ethiopia and importing countries real GDP.

As openness to trade of importing countries has a positive impact on Ethiopia's coffee exports performance. As a result, policies of importing countries that eliminate Ethiopia's import duties or trade barriers should be encouraged which will have a contribution on openness to trade of importing countries as well as on Ethiopia's coffee exports performance.

One of the major concern, in order to improve Ethiopia's coffee exports performance, is to adopt policies which will permit favorable market environments includes the legal and judiciary system, the financial system, taxation, labor 
relations, investment procedures and customs administration, UNCTAD [21], should be encouraged. Since the coefficient, Ethiopia's institutional quality has positive effects on Ethiopia's coffee exports performance.

Acknowledgements We would like to thanks our almighty GOD for every gifts and the people who contributed in one or other ways to this sake.

Open Access This article is distributed under the terms of the Creative Commons Attribution 4.0 International License (http://creativecommons.org/licenses/by/4.0/), which permits unrestricted use, distribution, and reproduction in any medium, provided you give appropriate credit to the original author(s) and the source, provide a link to the Creative Commons license, and indicate if changes were made.

\section{Appendix: Ethiopian coffee importing countries}

\begin{tabular}{llllllll}
\hline 1 & Algeria & 24 & Indonesia & 47 & Russian Federation & 70 & Yemen \\
2 & Angola & 25 & Iran & 48 & Saudi Arabia & 71 & Zimbabwe \\
3 & Australia & 26 & Ireland & 49 & Senegal & & \\
4 & Austria & 27 & Israel & 50 & Singapore & & \\
5 & Bahrain & 28 & Italy & 51 & Slovakia & \\
6 & Belgium & 29 & Japan & 52 & Slovenia & \\
7 & Bulgaria & 30 & Jordan & 53 & Somalia & \\
8 & Canada & 31 & Kenya & 54 & South Africa & \\
9 & China & 32 & Korea, R. & 55 & Spain & \\
10 & Congo D. R. & 33 & Kuwait & 56 & Sudan & \\
11 & Cyprus & 34 & Lebanon & 57 & Swaziland & \\
12 & Czech R. & 35 & Lithuania & 58 & Sweden & \\
13 & Denmark & 36 & Malaysia & 59 & Switzerland & \\
14 & Djibouti & 37 & Mexico & 60 & Taiwan, China & \\
15 & Egypt & 38 & Morocco & 61 & Thailand & \\
16 & Finland & 39 & Netherlands & 62 & Tunisia & \\
17 & France & 40 & New Zealand & 63 & Turkey & \\
18 & Germany & 41 & Nigeria & 64 & Uganda & \\
19 & Greece & 42 & Norway & 65 & Ukraine & \\
20 & Guatemala & 43 & Pakistan & 66 & United Arab Emirates & \\
21 & Hong Kong & 44 & Poland & 67 & United Kingdom & \\
22 & Hungary & 45 & Portugal & 68 & United R. of Tanzania & \\
23 & India & 46 & Romania & 69 & United States & \\
\hline & & & & & & \\
\end{tabular}

\section{References}

1. Alemayehu G (2009) Fundamentals of international economics for developing countries: a focus on africa volume I: trade theory and policy. Addis Ababa University and African Economic Research Consortium. Addis Ababa, Ethiopia and Nairobi, Kenya 
2. Arellano M, Bond SR (1991) Some tests of specification for panel data: Monte Carlo evidence and an application to employment equations. Rev Econ Stud 58:277-297

3. Babatunde AM (2009) Can trade libralization stimulate export performance in Sub-Saharan Africa? J Int Global Econ Stud 67:15-43

4. Baltagi BH (2005) Econometric analysis of panel data, 5th edn. Wiley, Chichester

5. Blundell R, Bond S (1998) Initial conditions and moment restrictions in dynamic panel data models. J Economet 87:115-143

6. Dlamini SG, Edriss AK, Phiri AR, Masuku MB (2016) Determinants of Swaziland's sugar export: a gravity model approach. Int J Econ Finance 8(10):71-81

7. Egger P (2002) An econometric view on the estimation of gravity models and calculation of trade potentials. World Econ 25(2):297-312

8. Eyayu T (2014) Determinants of agricultural export in Sub-Saharan Africa: evidence from panel study. Am J Trade Policy 1(3):13-22

9. Hansen LP (1982) Large sample properties of generalized method of moments estimators. Econometrica 50:1029-1054

10. International Coffee Organization (ICO) (2015) ICO annual report, 2015

11. Krugman PR, Obstfeld M (2003) International economics: theory and policy, 6th edn. Princeton University, Berkeley

12. Mold A, Paulo S, Prizzon A (2008) Taking stock of the credit crunch-implications for development finance and global governance. OECD Development Centre working paper No. 277

13. National planning commission of Ethiopia (NPCE) (2016) Growth and transformation plan I (GTPI) report (2010/11-2014/15), vol I. Addis Abeba, Ethiopia

14. Nguyen BX (2010) The determinants of vietnamese exports: static and dynamic panel gravity approaches. Int J Econ Finance 2(4):112-129

15. Orindi MN (2011) Determinants of Kenya's exports: a gravity model approach. Int J Econ Political Integr 1(1):3-14

16. Roodman D (2009) A note on the theme of too many instruments. Oxford Bull Econ Stat 71(1):135-158

17. Roodman D (2009) How to do xtabond2: an Introduction to difference and System GMM in Stata. The Stata Journal 9(1):86-136

18. Sargan JD (1958) The estimation of economic relationships using instrumental variables. Econometrica 26:393-415

19. Shoham A (1998) Export performance: a conceptualization and empirical assessment. J Int Mark 6(3):59-81

20. Transitional Government of Ethiopia (TOE) (1991) Ethiopia's economic policy during the transition period (an official translation). Addis Ababa, Ethiopia

21. UNCTAD (2008) Export competitiveness and development in LDCs: policies, issues and priorities for LDCs for Action during and Beyond UNCTAD XII, UNCTAD/ALDC/2008

22. Wacziarg R (2001) Measuring the dynamic gains from trade. The World Bank Development Economics, Development Prospects Group, Policy research working paper, wps 2001

23. Windmeijer F (2005) A finite sample correction for the variance of linear efficient two-step GMM estimators. J Economet 126:25-51

24. Yishak T (2009) Determinants of Ethiopia's export performance: A gravity model analysis. Trade and development discussion paper No. 01/2009, BKP Development Research and Consulting, Germany

Publisher's Note Springer Nature remains neutral with regard to jurisdictional claims in published maps and institutional affiliations. 